\title{
Assessment of Solar PV Power Generation Potential in Centre Development Region of Romania
}

\author{
Tihamér-Tibor Sebestyén
}

\begin{abstract}
The Centre Development Region of Romania could be considered an underdeveloped region in terms of local electricity production. In the region the local electricity generation is not able to supply the regional energy consumption, furthermore two of six counties have no electricity generation. On the periphery areas of region still existing 69 villages without electricity and 245 villages are partially electrified. The Rural Development Programme for Romaina includes the rural electrification using renewable energy resources. However PV investments started to develop in the last years. This paper presents an assessment of the PV electricity generation potential and the already existing PV projects. Considering the geographical, climate, social and technical factors, the technical potential of PV electricity generation has been also estimated using different types of approaches. This paper presents an assessment of the PV electricity generation potential in CDR of Romania and estimates the existing opportunities for $\mathrm{PV}$ projects and clearly demonstrate the necessity of investment in solar PV projects.
\end{abstract}

Index Terms-Solar energy potential, PV electricity generation.

\section{INTRODUCTION}

After the Paris Climate Conference (COP21) climate change becames one of the most important priority in the European agenda. The outcomes of this conference indicate that we are faced with an exponential growth in renewable energy production and the fundamental plans in this terms are expected in the coming years [1]. Parties referred to, inter alia, renewable energy targets, energy efficiency standards, grid modernization, financial schemes to promote clean investments, environmental taxes, subsidy reforms, programs for low $\mathrm{CO}_{2}$ emission, [2]. In the COP21 the solar energy was highlighted as a clean energy system for electricity generation because of the low-carbon emission [3].

Despite all these facts the European Union will not achieve more than $27 \%$ share of renewable energy consumption by 2030 [1], [4], which implies a very modest annual growth (1 to $1.5 \%$ ) [5]. Romania has increased renewable energy share $6.1 \%$ between 2004 and 2012, and on 29th December 2015 $(12: 52 \mathrm{pm})$ the peak performance shows almost $27.8 \%$ (average rate $23 \%$ ) of power from green sources, which is well above the European average [6]. In this term the current Romanian renewable energy strategies need to be updated.

\section{THE RESEARCH AREA}

The Centre Development Region (CDR) of Romania is

Manuscript received February 1, 2016; revised June 2, 2016.

Tihamér-Tibor Sebestyén is with Babeș-Bolyai University, Romania (e-mail: sebesten_tiha@yahoo.com). situated in the centre part of Romania (Fig. 1), within the arc of the Carpathian Mountains, on the upper and middle courses of Mureș and Olt [7]. The region has a relief of a plateau, with East-West oriented valleys. CDR is crossed by the meridian $25^{\circ}$ East and latitude $46^{\circ}$ North [8].

The region having $34100 \mathrm{~km} 2$ is nearly the same size as Beligum's area, but in terms of the number of population has an average NUTs II. namely 2.36 million people $(12.4 \%$ from Romanian's population) [9]. The birth rate is low similar with the country' one and there is a process of demographic aging. $60 \%$ of the population lives in urban areas - in the 57 towns of the region. Braşov (74.9\%) and Sibiu (67.8\%) counties have a higher degree of urbanisation while in Harghita county the rural population is dominant $(55.7 \%)$ [7], [8]. From economic point of view, the low populated areas of the Apuseni Mountains from Alba County are the least developed. The most developed industrial areas are located in the southern part of the region (the cities of Brasov and Sibiu and their satellites) and are specialised in the automotive, machinery construction, chemical, textile and food industry [8].

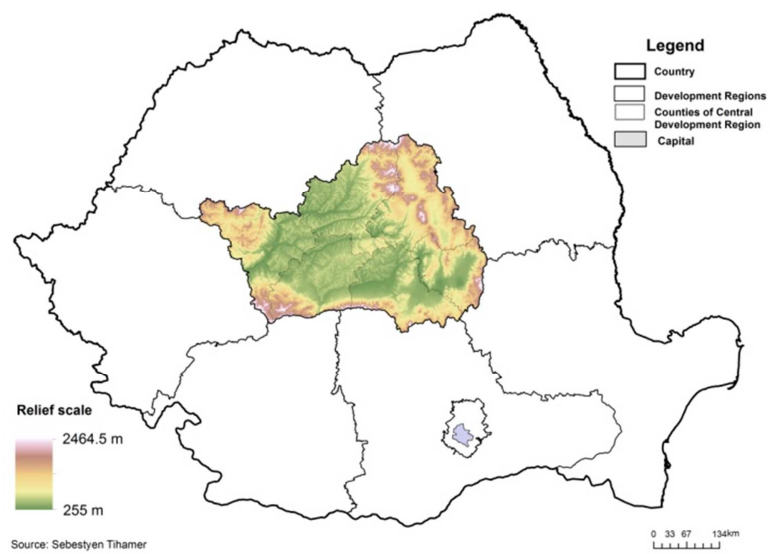

Fig. 1. The geographical location of centre development region in Romania

Regarding solar surface radiation CDR is enrolled in the European B category of sunlight with 210 sunny days, depending on geographical area, and the annual energy flow is between $1200-1500 \mathrm{kWh} / \mathrm{m} 2 /$ year [10], [11]. Solar surface radiation (Globaltot) is defined as the sum of direct (Dirtot) and diffuse (Diftot) radiation. The map of solar surface radiation was elaborated using ArcGIS 10.1 program. (Fig. 2). The map of global insolation was drawn with ArcGIS 10.1 program, where are repeated for every location on the topographic surface, producing insolation maps for an entire geographic area (Fig. 2).

Between 2000 and 2014 the average electricity consumption per capita in CDR was $2220.53 \mathrm{kWh} /$ year, which shows an increase of $8.48 \%$ [12]. The regional electric power generation (3 $436 \mathrm{GWh} /$ year) is able to supply only 
$64.49 \%$ of electricity consumption (5 $328 \mathrm{GWh} /$ year) [7]. Furthermore, two (Covasna and Harghita) of six counties have no electricity production, in the other counties the lack of electricity production versus consumption is $73.67 \%$ in Brasov, $73.47 \%$ in Sibiu, $8.03 \%$ in Alba. On the other hand in Mureș county the electricity production is $78 \%$ higher than the local consumption, because here we find the country's largest natural gas extraction and some gas power plant [13].

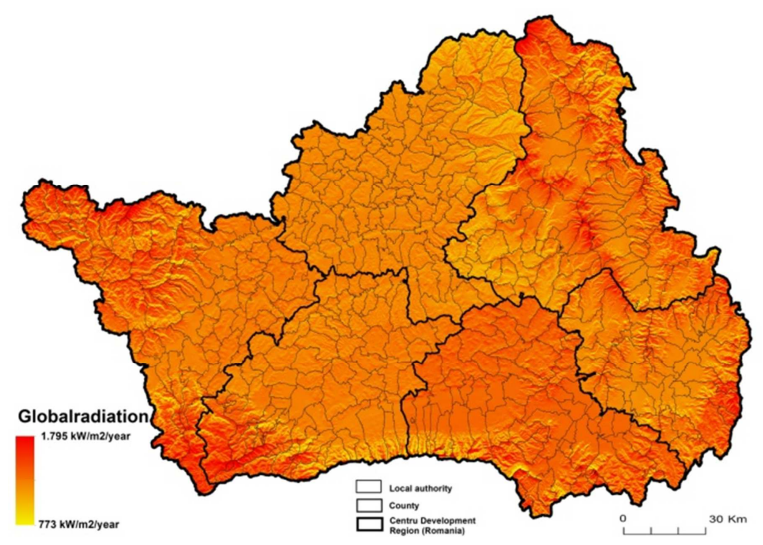

Fig. 2. Solar map of centre development region.

In CDR the main sources of electricity generation are natural gas and hydro energy [14], but the region is present in the renewable energy sector, particularly with the photovoltaic (PV) projects, which have started functioning since 2010. In the region the PV power plants grew the fastest compared to the other part of the country: in 2010 only 0.1 MW was installed, at the end of 2015 523.32 MW [15]. Between 2011 and 2013 the state supported the power producers with six green certificates (GC) for each delivered MWh (law 220/2008) and because of this, [16]-[18] the PV projects started to grow extremely (Fig. 3). However after January of 2014, when the number of GC has been reduced to half, (from 6 to $3.5 \mathrm{GC} / \mathrm{MWh}$ ), many PV projects have been cancelled similar to other renewable energy projects, even if the electricity consumption in the region still continue kept to grow [19].

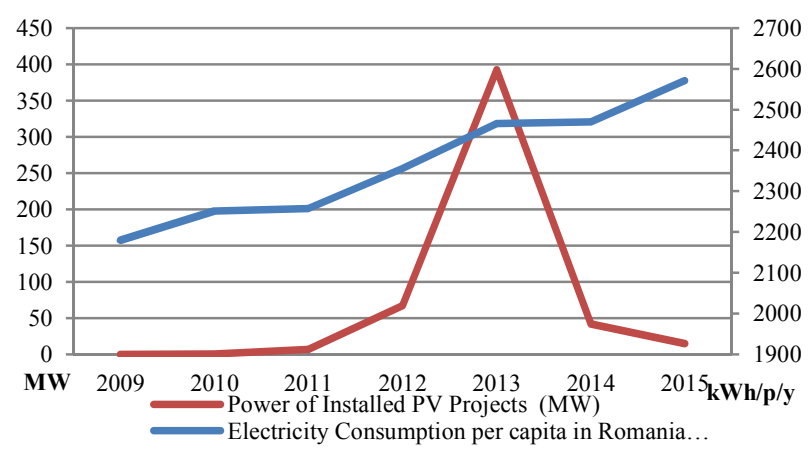

Fig. 3. PV Projects versus electricity consumption, source: Transelectrica SA., Index Mundi.

\section{PV ELECTRICITY GENERATION POTENTIAL IN CDR}

\section{A. Status of PV Electricity Generation in Region}

As we see in Fig. 4, currently the PV energy is considered as the most important renewable technology in region. Almost 523,32 MW of new PV capacity, altogether 139 projects have been constructed, which are corresponding to
78 municipality areas in researched region [15]. More than $25 \%$ of Romanian PV power plants are here installed and they are $100 \%$ grid-connected (see Fig. 5). Even though PV system's costs are consistently decreasing, the cost of investment in PV projects is approximately 784.5 Milion $€$ and the solar panels cover more than 1100 ha.

Interesting to note, that a Romanian and US Company together on 6th July 2012 launched Romania's first private Smart Grid project, in Ghimbav Industrial Park in Brasov county, with an investment of $\$ 15$ million into the production of energy from renewable sources [10]. The two companies installed photovoltaic panels in an industrial park in the city of Brasov and created the country's "first smart grid" private project.

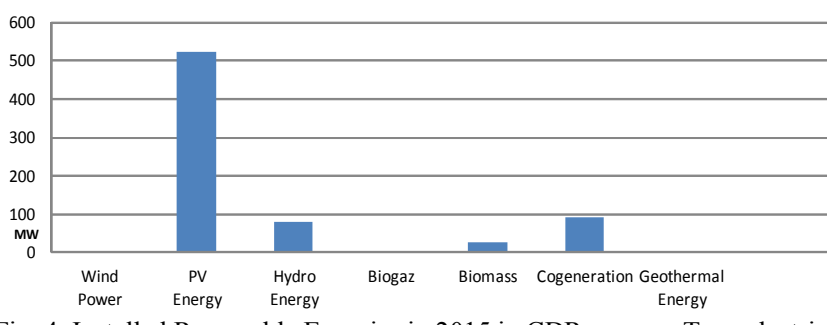

Fig. 4. Installed Renewable Energies in 2015 in CDR, source: Transelectrica SA.

From 2010 the "Green House Programme" subsidizes with app. $1350 €$ residential solar and thermal systems and also a small proportion of biomass systems. In the region, starting from the summer of 2011 has been analysed and approved altogether 7915 Solar Home System (SHS) projects: 1053 in Alba county, 1314 in Brasov county, 942 in Covasna county, 2403 in Harghita county, 1055 Mureș county and 1148 projects in Sibiu county [20].

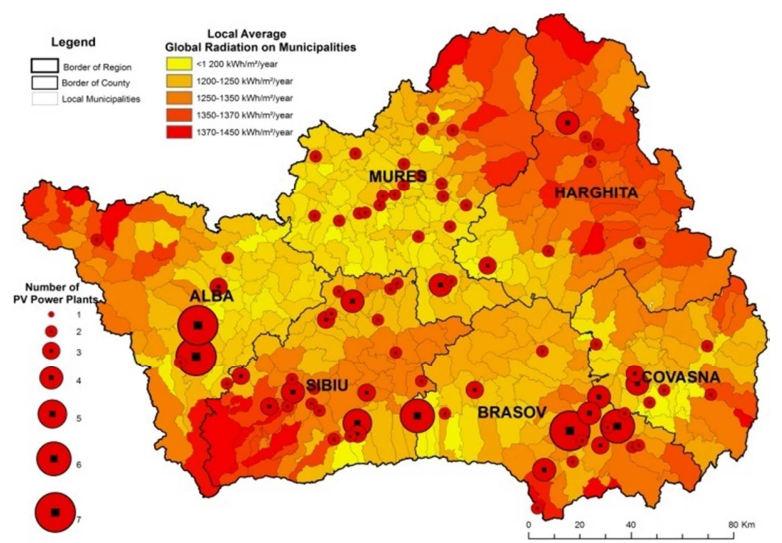

Fig. 5. Installed PV Projects and the surface solar radiation map of the region, source: Transelectrica SA.

The governmental program became very popular, the goal was to offer financial support for a large number of beneficiaries. However it was stopped for a while, therefore the invested sum of the financial support reached only 15 million $€$. The beneficiaries are mostly from those rural areas where electricity or thermal energy supply is not possible from the national grid, or where this is not cost-effective or desirable. Therefore off-grid PV systems are common in remote areas which are still not supplied by an electrical grid.

\section{B. Estimation of PV Electricity Generation Potential}

The solar energy potential is estimated starting from the SRTM digital elevation model (DEM). At the first step this 
TIN vector model with $25 \mathrm{~m}$ resolution is converted to raster DEM. The ArcGis 10.1 program of ESRI has a separate module incorporated, namely Solar Radiation based on DEM, dedicated to calculate the solar radiation components on the surface. The solar radiation analysis tools calculate insolation across a landscape or for specific locations, based on methods from the hemispherical viewshed algorithm [21]. Next step is the setting the sequence of the days in the investigated year, in this case 2015. The following step is to specify the input parameters which refer to the atmospheric conditions. Here two values shoud be adjusted, namely the proportion of diffuse radiation and the transmissivity of the atmosphere $\left(T_{a}\right)$. In this study the values of the proportion of diffuse radiation was taken from the PVGIS dataset [22]. The accuracy between the final modeled solar surface radiation values and observations shows an error of a couple of $\%$. One possible factor which can introduce inaccuracies consists these parameters strongly linked to the weather situations [23], but not analyzed in this study. The theoretical potential of solar energy can be estimated using the expression 1 [24]:

$$
G=K\left(S / S_{0}\right)^{0.63} \sin \cdot h^{-0.19}
$$

where $G$ is the amount of monthly average daily global radiation on a horizontal surface $\left(\mathrm{kW} / \mathrm{m}^{2} /\right.$ day $), S$ is the monthly average daily number of hours of bright sunshine, $S_{o}$ is the monthly average daily maximum number of hours of possible sunshine and $\mathrm{h}$ is the noon solar altitude on $15^{\text {th }}$ of the month. $K$ is a zone parameter that depends on the climate. As we see in Fig. 5, the PV potential of local administrative units is calculated with zonal statistics method. The average of the surface solar radiation in each municipality areas is calculated as the average of all grid cells in that zone.

In the process of the estimation, some social constraints such as land use, geographical area, climate and technical constraints are considered.

\section{1) On-grid solar PV systems}

In the study region, the installed PV projects are mainly connected to the national grid, consequently these are Centralized Grid Connected (CGC) PV applications. Since the CGC PV power stations are mostly installed on land surface with different characteristics, we need to assess the potential of surface. The potential of surface $\left(P S_{i}\right)$ of electricity generation through solar PV systems $(\mathrm{kWh} / \mathrm{yr})$ can be estimated using the equation 2 [25]:

$$
P S_{i}=I_{y} \cdot A_{s, i} \cdot 365
$$

where $I_{y}\left(\mathrm{kWh} / \mathrm{m}^{2} /\right.$ year $)$ is the average of solar surface radiation in the given area; $A_{S}\left(\mathrm{~m}^{2}\right)$ is the area suitable for installation of PV systems, $i$ is the area type, and 365 are the number of days in year. To estimate the area $(A s i)$ suitable for PV system installations, B. Sorensen introduced a new suitability factor $\left(f_{i}\right)$. This factor is the fraction of the area $(A i)$, available for installing the PV power plants. This area in area type $i$ can be estimated using the equitation 3 [25], [26]:

$$
\mathrm{A}_{\mathrm{s}, \mathrm{i}}=\int_{i} \cdot A
$$

where $A s i$ (ha) is the suitable area for PV system installations, $f$ is the suitability factor in area type $i$, A (ha) is the given area in the researched region.
From policy-related aspect the preservation of agricultural and forest areas is highlighted, but the degraded lands such as those affected by medium to high saline concentration, erosion, contaminated by heavy metals, could be an interesting option for the installation of new PV system. The suitability factors for different land use types [26] used in this study are shown in Table I. The suitable area for CGC PV investments in CDR is 22853.23 ha, which is about $0.70 \%$ of the total area of region [27]. The total amount of annual irradiance on this surface is estimated about $297 \times 10^{3} \mathrm{GWh}$ energy.

TABLE I: AsSUMED SUITABILITY FACTORS AND TOTAL SUITABLE AREA

\begin{tabular}{ccccc}
\multicolumn{5}{c}{ FOR CGC PV } \\
$\begin{array}{ccccc}\text { Land use } \\
\text { Type } \\
\text { Laitability } \\
\text { factor }(f \mathrm{i}) \\
{[26]}\end{array}$ & $\begin{array}{c}\text { Area per } \\
\text { land-use } \\
\text { type }\left(\mathrm{A}_{i}\right) \\
(\text { ha) }[27]\end{array}$ & $\begin{array}{c}\text { Land-use } \\
\text { area as } \\
\text { percentage of } \\
\text { total area }(\%) \\
{[27]}\end{array}$ & $\begin{array}{c}\text { Suitable area } \\
\text { for CGC PV } \\
\left(\mathrm{A}_{\mathrm{S}, \mathrm{i}}\right)(\mathrm{ha})\end{array}$ \\
\hline \hline Urban areas & 0 & 59106 & 2.733 & 0 \\
Forests and & 0 & 1246673 & 37.55 & 0 \\
bioreserve & 0.01 & 750930 & 22.72 & 7509.3 \\
Agriculture & 0.01 & 480899 & 14.577 & 4808.99 \\
Grassland & 0.01 & 645549 & 19.93 & 6455.49 \\
Pastureland & 0.05 & 81589 & 2.49 & 4079.45 \\
Wasteland & & 3264746 & 100 & 22853.23 \\
Total & & \multicolumn{4}{c}{} \\
\hline \hline
\end{tabular}

\section{2) Off-grid solar PV systems}

Off-grid solar PV systems or SHS have many applications opportunity in household energy supply: water pumping, operation of kitchen equipments, heating, etc. It is assumed that the decentralized PV applications are to be installed at roof-tops. The estimation of the potential of off-grid PV system is, therefore, practically the search for households in „roof reach area”, namely in rural villages. Moreover in CDR areas like this can be found in Munții Apuseni, Munții Călimani, Munții Giurgeului, Munţii Întorsurii, Munții Cindrel, Munții Baraolt, Munții Bodoc, Munții Persani, Munții Bârsei where in 245 villages a part of households are not connected to the national grid [7], [8].

Considering 2.36 million as the total population of CDR and 2.66 person for an average household, the total number of rural households (RHH) in region is 337726 (Alba county 49750, 49419 in Brașov county, 38457 in Covasna county, 64572 in Harghita county, 92528 in Mureș county and 43000 in Sibiu county) [9]. Taking into account that in the case of the CDR $3.3 \%$ of the households have no access to electricity, thus the number of RHH without access to electricity would be about 27413 households [28]. For these households, the supply of electricity using PV system would be highly recommended.

Assuming that each household without electricity would be equipped with HIP-200 BA solar panels, suitable for supplying the electricity needs for an average household. The technical potential of the off-grid PV system can be estimated using the equation 4 :

$$
E P P=R H H_{2011} \cdot G R S_{\mathrm{sec}} \cdot C U F \cdot 365
$$

where $E P P(\mathrm{kWh} /$ year) is the annual electricity production potential of the equipment, $R H H_{2011}$ is the number of rural households registered at last census (2011), GRS $S_{\text {set }}$ is the surface solar radiation in the given settlement, $C U F$ is the 
capacity utilization factor, which is decided by the solar insolation characteristics at the site; since CDR is located in a good solar insolation belt, CUF for solar PV applications is considered $20 \%$, and 365 is the number of days in a year. Using the equation 4 , the annual technical potential of off-grid PV systems in rural households is $89705 \mathrm{MWh} /$ year. This value in case of different counties is: $13111 \mathrm{MWh} /$ year in Alba county, $14400 \mathrm{MWh} /$ year in Brașov county, 9521 MWh/year in Covasna county, $14683 \mathrm{MWh} /$ year in Harghita county, $26759 \mathrm{MWh} /$ year in Mureș county, and 11321 $\mathrm{MWh} /$ year in Sibiu county. This value represents only $1.71 \%$ of the current electricity consumption.

Other studies [25], [29] have assessed the roof-top area per capita for the use of PV applications. The IEA studies focuses on various case studies, and includes orientation and morphological aspects concerning the architecture of the buildings. Other study [30] estimates the roof area from the ground floor area of buildings per capita. Hoogwijk propose [31] to relate the available area (roof-top) to income, namely to the GDP per capita. The roof-top area per capita $\left(R_{c, i}\right)\left(\mathrm{m}^{2}\right.$ cap-1) in grid cell $i$ as a function of the GDP per capita is expressed as follows 5 [31]:

$$
R_{c, i}=G D P_{i} \cdot 0.06
$$

The suitable area for roof-top PV applications in CDR is estimated $100.69 \mathrm{~km}^{2}$ as shown in Table II, which represents $0.29 \%$ of the total area of region. The total amount of annual solar surface radiation on the studied region is estimated $130.9 \times 10^{3} \mathrm{GWh} /$ year.

TABLE II: SUITABLE AREA FOR OFF-GRID PV SYSTEM IN CDR

\begin{tabular}{ccccc}
\hline County & $\begin{array}{c}\text { GDP per } \\
\text { capita }(€)\end{array}$ & $\begin{array}{c}\text { Roof-top area } \\
\text { per capita }\left(\mathrm{m}^{2}\right)\end{array}$ & $\begin{array}{c}\text { Population } \\
(2011) \\
{[12]}\end{array}$ & $\begin{array}{c}\text { Suitable area for } \\
\left.\text { SHS (Million } \mathrm{m}^{2}\right)\end{array}$ \\
\hline \hline Alba & 7609 & 45.654 & 342400 & 15.63 \\
Brașov & 9313 & 55.878 & 549200 & 30.68 \\
Covasna & 5305 & 31.83 & 210200 & 6.69 \\
Harghita & 4907 & 29.442 & 310900 & 9.15 \\
Mureș & 5962 & 35.772 & 550800 & 19.70 \\
Sibiu & 7898 & 47.388 & 397300 & 18.82 \\
\hline \hline Total & \multicolumn{4}{l}{100.69} \\
\hline \hline
\end{tabular}

Finally, the technical potential of PV electricity generation in CDR can be calculated using expression 6 [27]:

$$
T P=\sum G P \cdot \eta_{\mathrm{m}} \cdot p r
$$

where $\eta_{m}$ is the PV module's conversation efficiency, it is defined as the ratio of energy output from the solar cell to input energy from the sun. In the last 10 years, the efficiency of common commercial wafer-based silicon modules increased from about $12 \%$ to $16 \%$ [32]. The performance ratio $p r$ is stated in $\%$ and describes the relationship between the actual and theoretical energy outputs of the PV plant. Thus it shows the proportion of the energy that is actually available for export to the grid after deduction of energy losses (e.g. due to thermal losses and conduction losses) and of energy consumption for operation [33]. The results of technical potential of off-grid solar PV systems in CGC and are presented in Table III. The sum of estimated technical PV potential in CDR for on-grid and off-grid applications is $48.13 \mathrm{TWh} /$ year.
TABLE III: TECHNICAL POTENTIAL OF CGC AND SHS

\begin{tabular}{ccccc}
\hline \hline & $\begin{array}{c}\text { Geographical } \\
\text { potential } \\
(\mathrm{TWh} / \text { year })\end{array}$ & $\begin{array}{c}\text { Module } \\
\text { efficiency } \\
(\eta \mathrm{m})\end{array}$ & $\begin{array}{c}\text { Performance } \\
\text { ratio of PV }(\mathrm{pr})\end{array}$ & $\begin{array}{c}\text { Technical } \\
\text { potential } \\
(\mathrm{TWh} / \text { year })\end{array}$ \\
\hline \hline CGC & 297 & $16 \%$ & 0.75 & 33.41 \\
PV & 130.9 & $16 \%$ & 0.75 & 14.72 \\
SHS & $13 \%$ & 48,13 \\
\hline \hline Total & & & & 4 \\
\hline \hline
\end{tabular}

\section{Mitigation OF CARBON EMISSION IN CDR, USING SOLAR ENERGY SYSTEMS}

The impact of the conventional energy technologies (coal power plan, oil-fired power station) on the climate can be characterised by their carbon emission intensity, a measure of the amount of $\mathrm{CO}_{2}$ or $\mathrm{CO}_{2}$ equivalent emitted per unit of energy generated. The fossil fuel technologies result high carbon emissions through the combustion of carbon rich fuels, while in the case of renewable technologies such as solar technology little or no emissions will occur during functioning (electricity-or thermal power generation). Emissions are present only during their manufacture. Thus solar energy technologies can play a role to mitigate carbon emissions by replacing the carbon intensive sources of heat and power. The amount of emissions mitigated depends on the amount of conventional heat or power that is displaced, the carbon intensity of the displaced energy sources, and the amount and type of energy that is consumed in manufacturing, installing and operating of the solar energy system [34]. In the period of 2000 - 2014 the heat power capacity (utilization of coal and natural gas) was reduced from 2205492 $\mathrm{Gcal} /$ year to $303417 \mathrm{Gcal} / \mathrm{year}$ in the studied region. One small part of this is due the switch to biomass energy, however $86.3 \%$ still means the shrinkage of heat power stations capacity [35]. As mentioned above the annual technical potential capacity for off-grid solar energy of households is $14.72 \mathrm{TWh} /$ year. According to [35] the $\mathrm{CO}_{2}$ emission per $\mathrm{kWh}$ of energy production in Romania is 413.44 gram. If this amount of energy would be produced by off-grid solar systems we could save 6085861.82 ton $\mathrm{CO}_{2}(1265$ 691.84 toe) emitted into our environment [36]. Considering the annual technical potential for on-grid solar energy (Table III) which is $33.41 \mathrm{TWh} /$ year, by producing this amount of electricity using on-grid PV systems by we could save 13813 087 ton $\mathrm{CO}_{2}$ emission, which is equivalent with 2872742 toe [36].

However, the replacement of carbon-based electricity production with solar technology depends not only on the technology, but also on the way of where and how it is produced. The mitigation of $\mathrm{CO}_{2}$ emission due $\mathrm{PV}$ systems could be greater when the peak capacity is achieved [34].

\section{CONCLUSION}

This paper discusses the solar energy potential in Centre Development Region of Romania. The need to reduce the dependence from the national electricity supply is particular highlighted for mountain area of Alba county, but also for Covasna and Harghita county, where the local electricity production is $0 \mathrm{kWh} /$ year. As Fig. 2 shows the investors are ready to invest in this sector, but they are still depending on the state subsidies. The detailed estimation and assessment of 
solar energy potential clearly demonstrates that solar PV systems have a great potential to face the country's electricity needs in the future.

From the other hand the installed on-grid PV power stations are not adapted to local solar potentials, and they are not environmental sensitive, rather satisfy the legitimate expectations to receive the GCs. The current legislation obliges all renewable energy producers to introduce the energy in the national grid, and only the juridical persons could connect to the national grid, thus the local citizens are not directly profiting from the exploitation of renewable resources. In this case in the region, but also on national level, can observe a growth of solar energy use, but it is reserved from investors, thus no have local/regional development impact.

In these circumstances, the local producers will have practically no relation with produced energy and should not benefit from it in terms of cheaper energy prices, energy self-sufficiency or decentralized energy supply. This reality raises concerns of the future level of acceptance and support for such projects from citizens and local authorities because of a missing sense of ownership.

\section{REFERENCES}

[1] K. Ross and T. Damassa, "Assessing the Post-2020 Clean Energy Landscape," World Resources Institute (WRI), Technical Note, pp. 1-26, November 2015.

[2] United Nations, "Synthesis report on the aggregate effect of the intended nationally determined contributions," in Proc. COP21, Conference of the Parties, Twenty-First Session, Paris, November 30 December 12, 2015, pp. 1-66.

[3] World Energy Council, "Energy and climate change - special briefing for COP21," World Energy Outlook, International Energy Agency, pp. 1-9, December 2015

[4] European Commission, A Policy Framework for Climate and Energy in the Period From 2020 to 2030, Brussels, January 22, 2014.

[5] R. de Vos, P. van Breevoort, N. Höhne, T. Winkel, C. Sachweh, "Assessing the EU 2030 climate and energy targets," A Briefing Paper, Ecofys Netherlands B.V., Utrecht, March 17, 2014.

[6] B. Beetz. (June 2015). PV exceeds 2020 EU renewable energy target. Photovoltaic Markets \& Technology, PV Magayine. [Online]. pp. 1-3. Available:

http://www.pv-magazine.com/news/details/beitrag/pv-exceeds-2020-e u-renewable-energy-target-_100019858/\#axzz3wPSW5OK6

[7] Analiza socio-economică a Regiunii Centru, Planul de Dezvoltare a Regiunii Centru 2014-2020, Agentia pentru Dezvoltare Regionala Centru, Nr. 1215.07.2014, Alba Julia, 2014, pp. 1-266.

[8] D. Regională, Strategia de Specializare Inteligentă a Regiunii Centru, Agentia pentru Dezvoltare Regionala Centru, 2014, pp. 1-126.

[9] Recensamântul Populației și al Locuințelor-2011, Institutul Național de Statistică, București, 2011, pp. 1-14.

[10] M. Păceșilă, "Analysis of the Balkan countries policy on renewable energy sources: The case of Bulgaria, Romania and Greece," Management Research and Practice, vol. 5, issue 1, pp. 49-66, 2013.

[11] Romanian Photovoltaic Industry Report. China New Energy Chamber of Commerce (CNECC). (2013). [Online]. pp. 1-33. Available: http://www.cnecc.org.cn/uploadfile/Solar\%20Energy\%20in\%20Roma nia.pdf

[12] Electricity Consumption Per Capita in Romania, CIA the World Factbook 2015-06, Washington, DC: Central Intelligence Agency.

[13] V. Rajaram, Z. Siddiqui, and M. E. Khan, From Landfill Gas to Energy, Technologies and Challenges, CRC Press, 2012, p. 287.

[14] Regiunea Centru Premise și Potențial de Dezvoltare, Agenția pentru Dezvoltare Regională Centru, p. 26, 2010.

[15] Contracte de racordare incheiate de 10.12.2015. Transelectrica.

[16] A. Jäger-Waldau, PV Status Report 2014, European Commision, Institute for Energy and Transport, pp. 1-54, November 2014.

[17] J. Berg, "Q2 halt to UK utility-scale PV triggers new wave of consolidation among European EPCs," in Top Solar Industry Trends for 2015, IHT Technology, Solar Team, pp. 17-21, 2015.
[18] L. Fara, "Trends in PV Technolohies and market," presented at the 12th WEC Central \& Eastern Europe Regional Energy Forum-Foren 2014, June 22-26, 2014.

[19] C. Glodeanu. (February 16, 2015). Policy change slows PV installations. $P V$ Magazine. [Online]. 4(2). Available: http://www.pv-magazine.com/news/details/beitrag/romania-installs-3 63-mw-of-pv-in-2014_100018227/\#axzz3wVxI6UFs

[20] Database of Administratia Fondului Pentru Mediu, Ministry of Environment, Water and Forest, Bucuresti, April 27, 2015.

[21] P. M. Rich, R. Dubayah, W. A. Hetrick, and S. C. Saving, "Using view shed models to calculate intercepted solar radiation: Applications in ecology," American Society for Photogrammetry and Remote Sensing Technical Papers, pp. 524-529, 1994.

[22] Photovoltaic Geographical Information System (PVGIS). Interactive access to solar resource and photovoltaic potential. Institute for Energy and Transport (IET). [Online]. Available: http://re.jrc.ec.europa.eu/pvgis/apps4/pvest.php\#

[23] B. Bartók, Z. Imecs, and K. Tar, "Modeling radiation conditions of Hernád-valley in GIS Environment," Collegium Geographicum 8, Sepcial Edition, pp. 59-63, Cluj-Napoca, 2011.

[24] M. Chegaar and A. Chibani, "A simple method for computing global solar radiation," Renewable Energy Rem. Chemss, pp. 111-115, 2000.

[25] K. Harijan, M. A. Uqaili, and K. Mirza, "Assesment of solar PV power generation in Pakistan," Journal of Clean Energy Technologies, vol. 3, issue 1, pp. 1305-1309, January 2015.

[26] B. Sorensen, "Long term scenarios for global energy demand and supply," Four Global Greenhouse Gas Mitigation Scenarios, Roskilde University, Denmark, p. 213, 1999.

[27] Suprafata Fondului Funciar Dupa Modul de Folosinta in Regiunea Dezvoltare Centru, Institutul National de Statistica, January 2015.

[28] Planul de Dezvoltare al Regiunii Centru Pentru Perioada 2007-2013, Agenitia de Dezvoltare Recionala Centru, Alba Julia, pp. 1-149, 2008.

[29] E. Alsema and M. van Brummelen, "Het potentieel van pv-systemen in OECD landen," Utrecht University, Department of Science, Technology and Society, p. 53, 1993.

[30] Trends in Photovoltaic Applications in Selected IEA Countries between 1992 and 1999, IEA/OECD, Paris, 2000.

[31] M. Hoogwijk, "On the global and regional potential of renewable energy sources," Ph.D. dissertation, Dept. of Science, Tech. and Society, Utretch Univ., Netherlands, 2004.

[32] Photovoltaics Report. Frauhofer Institute for Solar Energy Systems, ISE, Freiburg. (November 17, 2015). [Online]. Available: http://www.ise.fraunhofer.de

[33] Performance ratio. Qualitätsfaktor für die PV-Anlage, Technische Information, SMA Solar Technology AG. [Online]. pp. 1-9. Available: http://files.sma.de/dl/7680/Perfratio-UEN100810.pdf

[34] J. Nelson, A. Gambhir, and N Ekins-Daukes, "Solar power for $\mathrm{CO}_{2}$ mitigation," Grantham Institte for Climate Change, pp. 1-16, Nr. 11, January 2014.

[35] Energia termica distribuita pe judete si localitati. Institutul National de Statistica. [Online]. Available: http://statistici.insse.ro/shop/

[36] Sun Earth Tools. $\mathrm{CO}_{2}$ emissions. [Online]. Available: $\mathrm{http}: / / \mathrm{www}$.sunearthtools.com/en/tools/ $\mathrm{CO}_{2}$-emissions-calculator.php

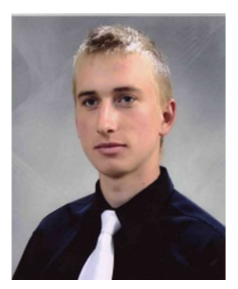

Tihamér-Tibor Sebestyén was born in Târgu Secuiesc, Romania on April 15, 1990. He received $\mathrm{BSc}$ in geography, BSc in territorial planning and MSc in territorial planning, in Cluj-Napoca, 2014, at Babeș-Bolyai University.

Over the past 6 years, he has specialised in the areas of renewable energy and clean energy and he work as young researcher in this field.

$\mathrm{He}$ has joined the Green Energy Romanian Innovative Biomass Cluster as researcher in August 2014. Since 2015, he is a $\mathrm{PhD}$ student at the Faculty of Geography, Babeș-Bolyai University, Cluj-Napoca, Romania. His researcher activities cover a range of environmental energy topic, including solar and wind energy, biomass, waste management, power plants, rural development with renewable energies. He is the author of 11 scientific articles.

Sebestyén has a work experience in an international workshop "Conflict of environmental protection and agriculture: a case of the Vransko jezero Nature Park", University of Zadar, Croatia. The topic of his main publications are "Sustainable Development of Less-Favoured Rural Areas: A Comparative Study of the Romanian and Austrian Experiences," "Rural Development Impact of Renewable Energies in Covasna County," "Biomass, Stimulatory Effect on Economy in Covasna County". He was awarded from Forerunner Federation, Virginia, USA, Research Fellowship Porgram 2013-2014. 